\title{
プラズマ荷電による微粒子の分級と物質の同定
}

\author{
黒部 利 次* 今 中 治** 池 野 昌 彦***
}

\section{Fine Particle Classification and Identification by Using Glow Discharge}

by

\section{Toshiji Kurobe*, Osamu ImanakA** and Masahiko Ikeno***}

A plasma-assisted fine particle classification and identification method has been developed by using a Geisler tube with a coneshape electrode. A particle is charged in plasma, in which its surface is covered with the sheath made of double layer of negative and positive ions. The charged particle flies to the positive electrode under high voltage. The flying mode, however, is influenced by the gravity, the collision of plasma ions with the flying particles and the viscosity of the constituent non-charged gas molecules. The newly-developed classification setup is made with three main parts; the Geisler tube, a powder supplier and an evacuation system. The fine powders such as alumina, silica, silicon carbide were classified under the condition of DC voltage of $500 \mathrm{~V}$ and the tube current of $30 \mathrm{~mA}$ at 2.0 Torr $\left(2.7 \times 10^{2} \mathrm{~Pa}\right)$. It is found from the experiments that the finer particles fall down near the upper side of cone electrode, but the coarser ones fly apart from it and that the grains with different mechanical and physical properties can be identified.

キー・ワード：分級，グロー放電，微粉，物質の同定

\section{1 緒言}

近年，電子材料，セラミックス等の分野では高品位 に分級された微粒子に対する需要が次第に大きくなっ てきている。一般に，分級は微粒になるにつれて難し くなる. 微粒子分級法の一つとして前報で，プラズマ を援用した微粒子分級法の実験的検討結果について報 告した，分級は，ガイスラー放電管中の陽光柱部に被 分級微粉を自然落下の形で供給することにより行った. 実験から，プラズマを利用して粒子分級が行えること が明らかとなった．しかし，本分級法は粒子の一方向 飛翔の形式をとっており，生産性の観点からさらに工 夫が必要と感じられた。

本研究は, 粉体の飛翔方向を $2 \pi$ ラジアンとし, 粒 子が鉛直下方に飛翔する形式の分級法について実験的 検討を行ったるのである，すなわち，粉体を上部電極 円形開口端より供給し，下方に配置されている円すい （萃型）電極へ飛翔させる形式の分級法について 検討 した.ささらに本研究では, 異種粒子が混在する微粉体 のいわゆる物質分級の可能性についても調べたそその 結果幾つかの興味ある知見が得られたので報告する。

\section{2 分 級 原理}

分級を行らガイスラー管内の放電状態を Fig. 1 に 示す.ガイスラー管に直流電圧が印加されると，管内 には図に示すよらな放電じま（模様）が生ずる。それ らの明暗部は上から, Aston暗部, 陰極グロー, Crooks
暗部，負グロー，Farady 暗部，陽光柱，陽光柱暗部， 陽光グローとそれぞれ呼称されている. 図に示すよう に, それらの各部で輝度や電位, 電場の強さ, 空間電 荷, 負・正電荷密度の值が異なる. 被分級粉体は図に 示すように, 上部電極円形開口端より供給される.

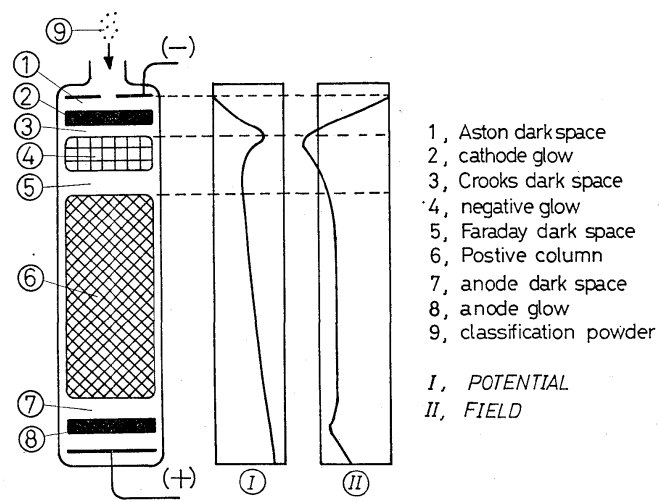

Fig. 1. Schematic illustration of particle classification.

いま，管内のプラズマは安定であるとし，その中へ 粉末粒子が 1 個自然落下する場合を考える. その際粒 子は帯電していないものとする.プラズマは電子とイ オンによって構成される準中性の気体であるので, そ の領域へ粒子が侵入するとプラズマの中性が破られ, 直ちに電子が粒子に飛来することになる。すなおち, 粒子は負に带電する.つぎに，その負電荷を打ち消す

$t \quad$ 原稿受理 昭和60年8月14日 Received Aug. 14, 1985

* 正会員 金沢大学工学部 金沢市小立野, Faculty of Engineering, Kanazawa University, Kodatsuno, Kanazawa

** 正会員 富山職業訓練短期大学校 魚津市川縁, Toyama Vocational Training College, Kawahuchi, Uozu

*** 金沢大学大学院 金沢市小立野, Graduate Student, Kanazawa University, Kodatsuno, Kanazawa 
ベくプラス電荷をもったイオンが粒子の表面に飛来す る. 前報で考察したよらに，粒子はシース (Sheath) という衣を被った状態となる，すなわち，粒子表面に は負電荷と正電荷のいわゆる電気二重層が形成される. Fig. 2 にその様子を示す. 前報での解析から表面の電 荷量 $Q$ は次式で与えられる.

$$
Q=\pi r^{2} N\left\{q_{e} n_{e}<C_{e}>\left(1+e^{-\left(\nabla_{s} / T_{e}\right)}\right)-2 q_{i} n_{i}<C_{i}>\right\}
$$

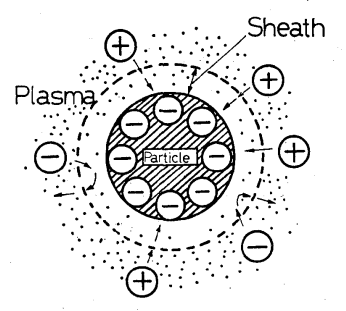

Fig. 2. Charging model of particle.

ここで， $r$ は粒子を球と仮定したときの半径， $N$ は単 層の電子吸着時間, $q_{e}, q_{i}$ は電子, イオン 1 個当りの 電荷量, $n_{e}, n_{i}$ は単位面積当りに飛来する電子, イオ ン数, $\left\langle C_{e}\right\rangle,\left\langle C_{i}\right\rangle$ は電子, イオンの平均速度, $V_{s}$ はシース電位, $T_{e}$ は電子温度相当電圧值である.

シースといら衣を被った帯電粒子がプラズマ管に入 るわけであるが，そこでは管軸方向に電場 $E_{z}$ が作用 しているため，粒子には

$$
F_{1}=Q E_{z}
$$

なる力が働くことになる. 粒子はこれらの力を受けて プラズマ管内を飛翔する，帯電量は式(1)から粒径に依 存するので, 粒径の大小によって㗢く力も異なること になる、すなわち，分級は粒子の飛翔状態を計測する ことによってなされる.

\section{$3 \cdot 1$ 分級装置}

\section{3 実 験 方 法}

作製した円すい電極型粒子分級装置の模式図を Fig. 3 に示す. 装置は, アクリル大円筒容器上端部に粉体 供給装置(1)を配置し，内部に有孔円板電極(2)，有孔円 すい電極 I 〜III(3)，バケット(4)を設置した構成となっ ている.さらに，プラズマを発生させるため，排気装 置と直流高圧電源が配置されている.

アクリル大円筒の大きさは, 内径 $300 \mathrm{~mm}$, 外径

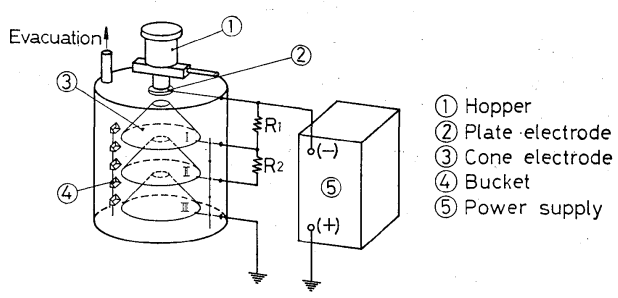

Fig. 3. Classification setup.
$320 \mathrm{~mm}$, 高さ $300 \mathrm{~mm}$ であり, 上端密閉, 下端開放 型となっている. 真空容器としてアクリルを使用した のは, 放電プラズマの状態が外から透視でき, 分級の 状況が目視で観察し得るためである. Fig. 3 に示す(3) の円すい電極はアルミニウム製（厚さ $0.8 \mathrm{~mm}$ ) であ $り$, 上端有孔直径 $30 \mathrm{~mm}$, 底面直径 $160 \mathrm{~mm}$, 斜辺 の長さ $100 \mathrm{~mm}$ の傘型である. I〜IIIの電極はいずれ も同じ寸法形状である. I , II， III の電極間隔は 80 $\mathrm{mm}$ 一定となっている. 上部有孔電極と円すい電極 I の間隔は $30 \mathrm{~mm}$ である. 捕集用バヶット(4)は円すい 電極に接して置かれ, 電極円周上に互いに90度の間隔 で 4 箇所配置されている. 図に示すように，鉛直方向 には $40 \mathrm{~mm}$ 間隔で紙製 $(40 \times 25 \times 15 \mathrm{~mm})$ のバケッ トが 5 個取り付けられている.

ここで, 粒子分級に有孔円すい電極(3)を用いたのは 次の理由による. Fig. 3 に示すように, 電圧の印加方 向および重力の作用方向が鉛直であり, 被分級粒子の 流れは下方になる，精密な分級を行うためには，粒子 の流れをできるだけ $2 \pi$ 方向に拡げる方が望ましい. 円板状電極を選定した理由である，また，とれを円す い(円すい角 $2 \alpha$ ) 状にすることによって, 飛翔距離 を $1 / \sin \alpha$ 倍に拡大できる.ただし， $\alpha$ が小さすぎる と被分級粒子が電極に付着することなく，すべる．両 者の摩擦係数を考慮して決めなければならない.

\section{$3 \cdot 2$ 粒子分級と物質分級の手順}

粒子分級試験は下記の手順により行った. (1)分級に 供する粉末粒子をデシケータ内に48時間以上保持し乾 燥を行う. (2)円すい電極扝よびバヶットを適正な位置 に配置し, 容器内をクリーンにした後密閉する. (3)デ シケータより粉末粒子を所定量取り出乙粉体供給装置 に入れる. (4)油回転 ポンプにより装置内を排気 し, $2.7 \times 10^{2} \mathrm{~Pa}$ (2.0 Torr) の真空度にする. (5)電極間に 直流電圧を印加（約 $500 \mathrm{~V}$ ) し, プラズマを発生（管 電流 $30 \mathrm{~mA}$ ) させる. (6)所要のプラズマが発生したら, 粒子落下口のふたを徐々に開けプラズマ管内に粉末粒 子を供給する. その際, 粒子の流れが滑らかとなるよ ら配慮した。

分級試験終了後次の方法で粒子径を測定した. 管内 を大気圧に戻した後, Fig. 4 に示す位置 . (1，2，3‥ の数字の位置) でサンプリングし, 光学顕微鏡で粒径 を測定した. 分級に供した粉体は，アルミナ $\mathrm{Al}_{2} \mathrm{O}_{3}$ (WA $\$ 1000)$, 炭化ケイ素 $\mathrm{SiC}(\mathrm{GC} \# 1000)$ ), シリカ

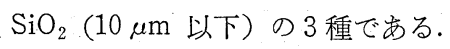

物質分級試験は次のように行った. 平均粒径のほぼ 等しいアルミナ, 炭化ケイ素, シリカの各粉体を等量 混合しデシケータ内で乾燥を行ら. 分級試験の方法は 先に記した粒子分級の方法と同じである. 試験終了後 の分級状態（物質分級）の観察はX線マイクロアナラ 


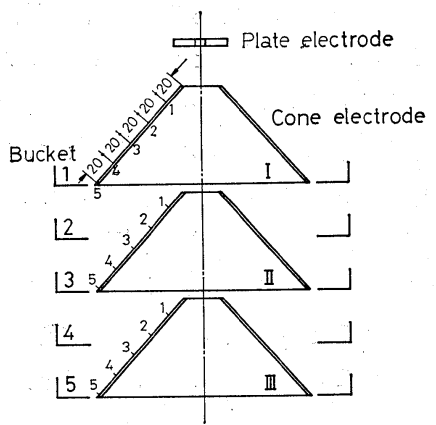

Fig. 4. Sampling position.

イザー（島津，EMX-SM 型）を用いて行った。

\section{4 実験結果および考察}

分級試験の一例を Fig. 5, 6 に示す. 図に扮いて, 円すい電極の場合は，横軸は電極上端部からの距離を 表し，縦軸は粒径を表している，バケットの場合は横 軸はバヶット番号を表している：図中のバーは粒径の

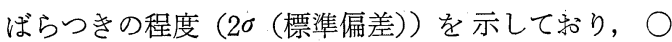
印は平均粒径を表す. 粒径の測定は，分級後撮影した 写真からランダムサンプリングにより 100 個の粒子を 抽出し, そのフェレー (Feret) 径を測定することに
より行った.

Fig. 5 は炭化ケイ素，Fig. 6 はアルミナの測定結果 を表している。これらの図から，粒径は円すい電極が I〜II几と移るにつれて大きくなることがわかる.ま た，電極を固定して眺めた場合，上部開口端からの距 離が増すにつれて粒径が大きくなる. バヶットでは， 円すい電極の場合よりも大きな粒子が補集される.

平均粒径のほぼ等しいアルミナ，炭化ケイ素，シリ 力微粉末を等量 (1 gr) ずつ混合した試料について分 級（物質分級）した結果を. Fig. 7 に示す. サンプリ ングは円すい電極Ｉについて行い，電極上端から20， 40，60，80，100 mm の各位置で両面接着テープによ り被検試料を採取した．X線マイクロアナライザーで 観察するため，微粉の付着しているテープを所定の寸 法 (8 mm 角) に切断し; 黄銅製支持台に貼り付け金 蒸着を行った. 面分析は $\operatorname{AlK} \alpha$ 線, $\operatorname{SiK} \alpha$ 線につい て行った. Fig. 7 で黒塗りの粒子はアルミナであり, 白奴きの粒子は炭化ケイ素またはシリカの粒子である. 図から明らかなように, 円すい上端から下端にいくに つれて炭化ケイ素, シリカの割合が減少し, 逆にアル ミナの割合が増加しているのがわかる。これはアルミ

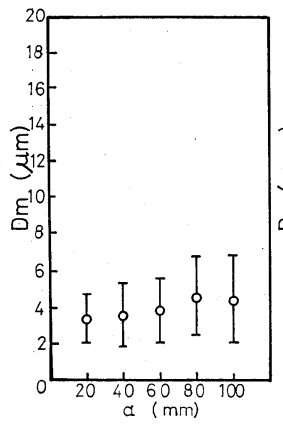

(a) Cone electrode I

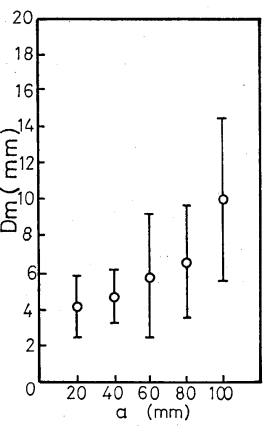

(b)

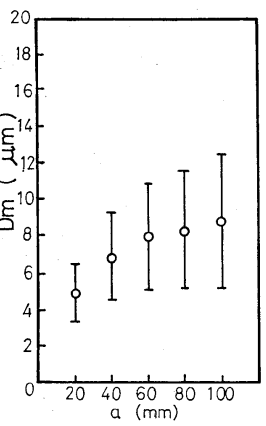

(c) II I

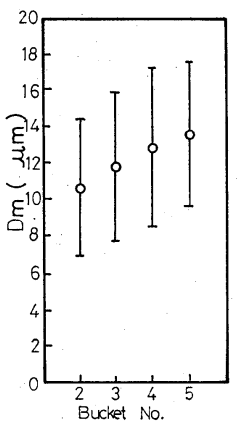

(d) Bucket

( Si C particle)

Fig. 5. Relation between particle size and flying distance (Silicon carbide).

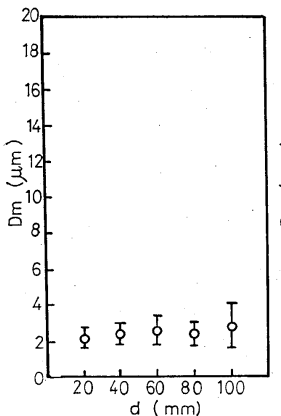

(a) Cone electrode 1

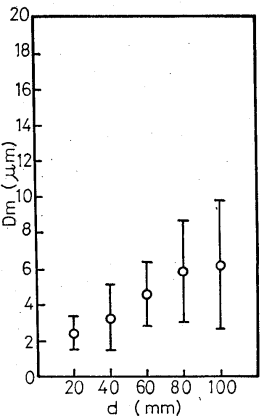

(b) II

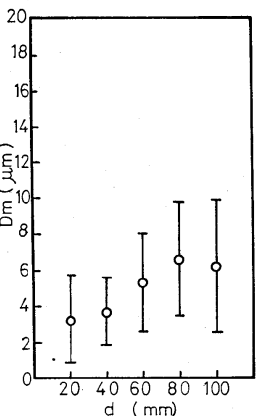

(c) III

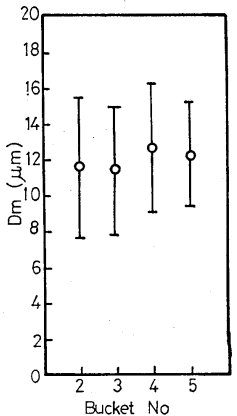

(d) Bucket

$$
\text { ( } \mathrm{Al}_{2} \mathrm{O}_{3} \text { particle) }
$$

Fig. 6. Relation between particle size and flying distance (Alumina). 


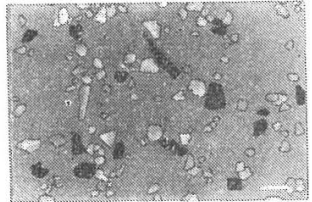

$20 \mathrm{~mm}$

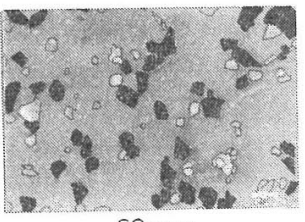

$60 \mathrm{~mm}$

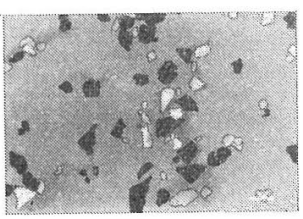

$100 \mathrm{~mm}$

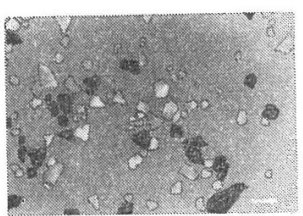

$40 \mathrm{~mm}$

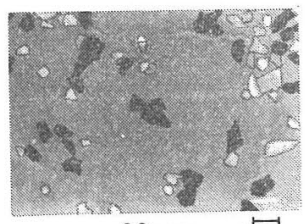

$80 \mathrm{~mm} \quad 10 \mathrm{tm}$

$\mathrm{Al}_{2} \mathrm{O}_{3}$

$0: \mathrm{SiC}$ or $\mathrm{SiO}_{2}$

DC400V,2.0mA $1.50 \times 10^{2} \mathrm{~Pa}$
Fig. 7. Particle identification.

ナが遠くへ飛翔したことを物語っている。すなわち， 物質分級が行わ就たことを意味している。

第 2 節の分級原理のところで記したよらに，被分級 微粉末はプラズマ中で带電し，電場から力を受けて飛 翔すると考兄られるが，Fig，5，6亿示した実験結果 はこれを実証したものとい光る。また，物質によって 带電状態に差異（物質によって誘電率が異なる）が生 ずると考兄られ，それがため異種混合粉体の各個物質 の飛翔距離に違いが生ずるはずである．Fig. 7 に示し た実験結果はこのことを実証したものと考光られる。

このよらに, 粒子分級は基本的にはプラズマ中に落 下した粒子が带電することにより行われるが，以下に

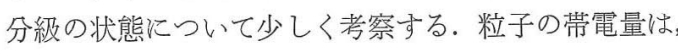
粒子の表面樍すなわち粒径 $d$ の 2 乗に比例すると考克 られる。乙たがって, 粒子の比带電量(帯電量/質量) は $1 / d$ に比例する。この比寡電量は粒子の飛翔を考克 る上で重要な因子と思われる，概括的に言党ば，比帯 電量が大きければ（ なり，電場から受ける力の影響が大きく，逆に小さけ れば（ $d$ が大 : 粗粒) 重力効果が著しくて, 電場から 受ける力の効果が小になる。このことは微粒活ど電極

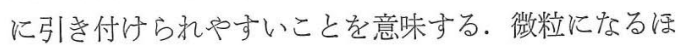
ど円すい電極上端側に捕足されるはずである。粗粒の 場合は，重力作用の他プラズマの流孔も影響を及ぼし ていると思われる。すなわら，アクリル樹脂を透して の目視から，粒子(粗粒) はプラズマから浮力とラジ アル方向への流孔作用を受けていると推察される。必 然粗粒子は遠くへ飛翔することになり，円すい電極の 外側の方に捕集されることになる。微粒の場合はこれ

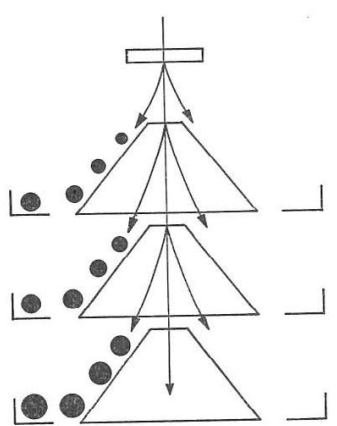

Fig. 8. Flying mode of particle.

らの作用は小さいと考えてよい。逆に，径の大きな粒 子の落下は遅く, 下端側に捕集されることになる。こ の様子を模式的に表せば Fig.8のようになる。これ らの考光は実駼結果とも大体合うように思われる。

分級空問内を飛翔する微粉粒には，プラズマ帯電に 基づく電磁力の他に, 重力やプラズマ中のイオンの衝 突ならびにイオン化していない気体からの浮力などを 受ける.Fig. 8 飞示すよらに，粒子はこれら力の合力 方向涂飛翔することになる。粒子の飛翔に影響を及洼 す因子としてこの他，(1)粒子の幾何形状，(2)粒子表面 の物理特性，(3)かさ比重，等を考慮しなければならな い, 生産性の立場からは，(1)粉体供給法に工夫が必要 であり, (2)效率的捕集法の開発等も必要とされる。

前報で述べた陽光柱利用の分級法と本円すい電極利 用 $2 \pi$ ラジアン法を比較した場合，本分級法は工業生 産性に優れているとい光る。しかし，Fig.1 (b)に示す ように，場所場所によって電位こう配が異なり，粒子 に作用する力も場所場所によって異なると思われる。 精密分級を行う場合このことを十分考慮しなければな らない。

\section{5 結 論}

$2 \pi$ 方位型プラズマ分級装置を試作して粒子分級害 験を行った結果，次のような結論が得られ，新しい粒 度分級法, 物質分級法としての可能性を確認した。

(1) アルミナ，シリカ，炭化ケイ素等の微粉関し て分級が可能で西ることを確かめた。

(2) 粒径のばらつきは, 円型開口端からの距離が長 くなるにつれて大きくなる。

（3）バケットに捕集される粒子は円すい電極上のる の上り大さい。

（4）アルミナ，シリカ，炭化ケイ素の物質分級が可 能であることを確認した。

(嘫和 57 年 5 月 25 日 日本材料学会第 31 期学術講演会にて請演)

\section{参 考 文 献}

1）黑部利次，今中 治，石橋信彦，材料，34，1352(1985).

2) 井保輝一郎, “粉体一理論と応用一”, p. 459 (1962) 丸 
善.

3）高分子学会編, “静電気ハンドブック”, p. 439 (1972) 地人書館.

4）Francis F. Chen 著, 内田岱二郎訳, “プラズマ物理入
門”, p. 23 (1977) 丸善.

5) 後藤憲一, “プラズマ物理学”, p.71 (1967) 共立出版.

6) 岡田 実, 荒田吉明, “プラズマ工学”, p. 197 (1965) 日刊工業新聞社.

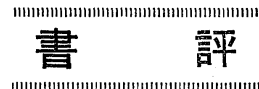

\section{"Polymer Permeability"}

\section{J. Comun (編)}

（1985年, Elsevier Applied Science Publishers Ltd. 発行, $23 \times 15 \mathrm{~cm}, 383$ ページほ45.00)

セラミックス，ガラス，金属などの材料とは異なり，高分子材料には物質（主として低分子）を透過する性質 があるのが一つの特徵である．この透過性があるが故に，高分子は材料として利点と欠点をもつ．たとえば，高 分子材料を容器として用いた場合は, 内容物の損失, 污染が問題となる. なた, 接着剤や繊維強化複合材料には 水の桩散による劣化が問題となる. 他方, 利点の例としては, 染色や薬物の分配などへの応用である.いずれに しても，透過性は高分子材料の実用化と深くかかわっている重要な性質である.

本書は最近数年間の高分子の透過性に関する基礎的研究の成果を⿱とめ，末た，応用研究の成果を集めたもの である. 第 1 章では拡散の数学的基礎が入門的に解説され，続く第 2 章では高分子系における気体透過現象の基 礎が解説されている. 第 3 章では高分子材料の応用上重要な問題と関連深いCase II 収着挙動についての解説 がある. 次につづく 6 章では, 酸素透過性と材料劣化の問題括よび安定剤との関連, 接着剤, 薬物の移送と分配 の制御, 包装材料, 電子材料やオプトエレクトロニクス・デバイスの被覆およびカプセル化と透過性の問題, 複 合材料に扮汁る水の透過とその影響など，透過性が問題になる応用分野における諸問題が具体的実例とともに論 じられている.

本書は, 食品包装, 製薬, 接着剤, 電子部品の製造など, 高分子材料を利用した分野の各産業に抺仔る研究 者，技術者に有益な内容をもつものである.

(京都大学工学部 浅田 忠裕) 